\title{
The Influence of Think Pair Share (TPS) Cooperative Learning Model and Initial Ability on Affective Competence Biology Class VIII of SMPN 38 Sijunjung
}

\section{Pengaruh Model Pembelajaran Kooperatif Tipe Think Pair Share (TPS) dan Kemampuan Awal terhadap Kompetensi Afektif Biologi Siswa Kelas VIII SMPN 38 Sijunjung}

\author{
Rini Silvina \\ Program Studi Pendidikan Biologi, STKIP Ahlussunnah Bukittinggi \\ rinisilvina@gmail.com
}

\begin{abstract}
The aim of this research was to reveal the influence of Think Pair Share cooperative learning model and initial ability on affective competence biology class VIII of SMPN 38 Sijunjung. This was a Quasi Experimental research which used 2 x 2 factorial design. The population of the research was the students in class VIII os SMPN 38 Sijunjung in academic year 2015/2016. By using saturated sampling technique, class $\mathrm{VIII}_{1}$ was chosen as the experimental class and class $\mathrm{VIII}_{2}$ was as the control class.Instrument used in this research is observation sheet filled by observer to see student affective competence.The results of the research revealed that Think Pair Share cooperative learning model exerted an influence upon affective competence of the students having either high or low initial ability.
\end{abstract}

Keywords: think pair share, initial ability, affective competence

\section{PENDAHULUAN}

Biologi adalah salah satu cabang IPA, yang menyediakan berbagai pengalaman belajar untuk memahami konsep dan proses sains. Biologi merupakan salah satu bidang studi yang penting, karena biologi merupakan ilmu sangat diperlukan dalam bidang ilmu lainnya.Pembelajaran biologi mengharuskan siswa untuk memahami konsep dan memahami penerapannya dalam kehidupan.

Pembelajaran yang terpusat pada siswa dapat meningkatkan keaktifan siswa dalam memahami pelajaran melalui pengalaman yang didapatnya langsung dalam kegiatan pembelajaran. Pembelajaran yang terpusat pada peserta didik bertujuan untuk mendorong motivasi, minat, kreativitas, inisiatif, inspirasi, kemandirian, dan semangat belajar. Siswa tidak dianggap sebagai objek pembelajaran, tetapi harus diberikan peran aktif serta dijadikan mitra dalam pembelajaran. Siswa bertindak sebagai agen pembelajar yang aktif, sedangkan guru bertindak secara fasilitator dan mediator yang kreatif (Rusman, 2012:08). 
Keaktifan siswa dalam proses pembelajaran sangat diperlukan agar dapat meningkatkan kompetensi belajar siswa. Timbulnya keaktifan siswa dalam kelas tidak terlepas dari peran seorang guru. Usman (2010:21) mengungkapkan bahwa seorang guru atau pengajar memiliki peran yang sangat penting dalam menentukan kualitas dan kuantitas pengajaran yang dilaksanakan dalam proses pembelajaran.

Berdasarkan wawancara peneliti pada bulan Agustus dengan siswa di SMPN 38 Sijunjung, diketahui bahwa umumnya siswa menyukai pembelajaran biologi karena materi pembelajaran relevan dengan kehidupan sehari-hari. Namun siswa juga menganggap pembelajaran biologi sebagai ilmu hafalan, sehingga siswa merasa bosan dan kurang termotivasi dalam mengikuti proses pembelajaran.

Pada saat proses pembelajaran siswa tidak mau mengeluarkan ide atau pendapatnya, karena siswa kurang memahami materi pelajaran dengan baik. Saat proses pembelajaran berlangsung kurang dari 50\% siswa yang bertanya dan menjawab pertanyaan dari guru. Hal ini mengakibatkan proses pembelajaran menjadi membosankan.

Peneliti juga melakukan observasi dan wawancara pada guru biologi SMPN 38 Sijunjung pada bulan Agustus, diketahui bahwa guru lebih sering menggunakan metode ceramah dan tanya jawab. Pembelajaran yang berpusat pada guru membuat siswa pasif dan tidak termotivasi dalam proses pembelajaran. Siswa tidak berani untuk mengeluarkan ide atau pendapatnya. Hal ini terlihat pada saat guru menjelaskan pelajaran, siswa tidak memperhatikan guru dengan sungguh-sungguh. Siswa hanya mencatat, meski tidak memahami apa yang mereka catat. Aktivitas belajar siswapun rendah dan terkadang ada siswa yang mengantuk, sehingga materi pelajaran yang diajarkan kepada siswa tidak terserap, dan mengakibatkan hasil belajar siswa rendah.

Penilaian yang dilakukan oleh guru hanya pada aspek kognitif saja yaitu melalui ujian, ulangan harian, dan beberapa tugas. Kompetensi belajar siswa tidak hanya pada ranah kognitif, tetapi mencakup pada ranah afektifyang memiliki peranan dalam mencapai hasil belajar yang baik. Pembelajaran yang tidak mengasah aspek sikapsiswa mengakibatkan kurangnya kemampuan berkomunikasi, berpikir kritis, analitik, sistematis, logis, tidak ada tanggung jawab dalam belajar, tidak ada kemampuan mencoba untuk mengerti dan toleran terhadap pandangan yang berbeda, serta rendahnya kerjasama diantara peserta didik.

Pada proses pembelajaran diperlukan kecakapan guru dalam mengatasi kesulitan mempelajari biologi terutama pada materi gerak, hama dan penyakit pada tumbuhan. Pada materi ini menuntut pemahaman konsep dan penalaran siswa.Siswa dituntut untuk berfikir kritis, logis, bersikap ilmiah, dan memahami konsep dengan benar.Pada proses pembelajaran siswa tidak aktif, karena metode yang digunakan oleh guru kurang bervariasi. Metode pembelajaran yang digunakan guru hendaknya mampu merangsang dan memotivasi siswa dalam pembelajaran. 
Ditinjau dari permasalahan tersebut, maka perlu usaha yang dapat meningkatkan mutu pembelajaran biologi yang lebih baik. Hal ini tidak terlepas dari faktor guru, siswa, materi, strategi pembelajaran, dan berbagai faktor lainnya.. Salah satu upaya yang dapat dilakukan guru untuk membantu siswa supaya aktif dan dapat memahami materi pelajaran adalah dengan menggunakan model pembelajaran kooperatif tipe Think Pair Share (TPS).

Model pembelajaran TPS merupakan model pembelajaran yang memungkinkan siswa untuk lebih aktif dan bertanggung jawab penuh untuk memahami materi pelajaran baik secara kolektif maupun individual. TPS memberi kesempatan pada siswa untuk bekerja sendiri serta bekerjasama dengan orang lain. Siswa tidak akan merasa takut untuk mengeluarkan ide kepada temannya, karena mereka akan saling berbagi informasi dan memecahkan masalah bersama. Hal ini sesuai dengan yang diungkapkan oleh Kartika (2012:11) bahwa belajar dengan menggunakan teknik Think Pair Share dapat meningkatkan keaktifan siswa dan membuat suasana kelas menjadi menyenangkan bagi siswa dalam berbicara tentang ide yang mereka dapatkan.

Pembelajaran kooperatif tipe TPS dapat meningkatkan keaktifan siswa dalam pembelajaran, karena memberikan waktu yang lebih banyak pada siswa untuk berpikir, menjawab, dan saling membantu satu sama lain. Hal ini telah dibuktikan oleh Pratiwi (2011) yang telah melakukan penelitian tentang tentang "pengaruh penerapan pembelajaran kooperatif Think Pair Share terhadap kemampuan matematika siswa kelas VII SMPN 1 Kecamatan Situjuh Limo Nagari”. Hasil penelitian tersebut menunjukkan penerapan model pembelajaran kooperatif tipe Think Pair Share dapat menigkatkan aktivitas dan kompetensi belajar siswa.

Penggunaan model TPS dapat mendukung keberhasilan siswa yang dimulai dari adanya kemampuan awal. Latar belakang siswa yang beragam dimungkinkan dapat mempengaruhi proses dan sikapbelajar siswa. Kemampuan awal dan model pembelajaran merupakan dua hal yang sangat penting untuk diperhatikan oleh guru sebelum memulai proses pembelajaran. Model pembelajaraan kooperatif tipe TPS dapat meningkatkan cara belajar siswa menuju lebih baik, karena mampu mengembangkan pengetahuan, kemampuan, dan keterampilan siswa. Siswa juga menjadi mudah dalam memahami pembelajaran, karena dalam pembelajaran guru mempertimbangkan kemampuan awal siswa dengan demikian diharapkan sikap siswa dalam belajar dapat lebih baik lagi.

Berdasarkan latar belakang diatas, maka penulismelakukan penelitian yang berjudul "Pengaruh Model Pembelajaran Kooperatif Tipe Think Pair Share (TPS) dan Kemampuan Awal terhadap kompetensi afektif Biologi Siswa Kelas VIII SMPN 38 Sijunjung". Penelitian ini bertujuan untuk mengetahui model pembelajaran kooperatif tipe think pair share (TPS) dan kemampuan awal terhadap kompetensi afektif biologi siswa kelas VIII SMPN 38 Sijunjung. 


\section{METODE PENELITIAN}

Jenis penelitian yang dilakukan adalah penelitian Quasi Eksperimental, dimana penelitian ini tidak dapat mengontrol semua variabel yang relevan kecuali beberapa variabel-variabel yang diteliti. Pada penelitian ini siswa dibedakan menjadi dua kelas yaitu kelas eksperimen dan kelas kontrol. Kelas eksperimen adalah siswa yang diberikan perlakuan dengan menggunakanmodel pembelajaran kooperatif tipe Think Pair Share, sedangkan kelas kontrolmenggunakan metode diskusi.Kemampuan awal siswa diperoleh dari 50\% siswa yang mencapai nilai urutan tertinggi dan kemampuan awal rendah siswa diperoleh dari 50\% siswa yang mendapat nilai rendah.Desain penelitian yang digunakan yaitu rancangan faktorial (factorial design) $2 \times 2$.

Populasi dalam penelitian ini adalahsiswa kelas VIII SMPN 38 Sijunjung yang terdaftar pada Tahun Pelajaran 2015/2016. Sampel yang digunakan yaitu siswa kelas VIII yang terdiri dari dua kelas yaitu kelas $\mathrm{VIII}_{1}$ dan kelas $\mathrm{VIII}_{2}$, jadi kedua kelas dijadikan sampel (simple random sampling). Cara menentukan kelas sampel dengan cara diundi, kelas yang mendapatkan undian pertama ditetapkan sebagai kelas eksperimen yaitu $\mathrm{VIII}_{1}$, dan yang kedua ditetapkan sebagai kelas kontrol yaitu $\mathrm{VIII}_{2}$.Penelitian inidilakukan di SMPN 38 Sijunjung. Penelitian dilaksanakan pada bulan NovemberTahun Pelajaran 2015/2016.

Instrumen yang digunakan dalam penelitian ini adalah lembar pengamatan yang diisi oleh observer untuk melihat kompetensi ranah afektif siswa. Lembaran penilaian ini bertujuan untuk menilai sikap dan prilaku siswa selama proses pembelajaranberlangsung.Lembar penilaian tersebut memuat aspek-aspek yang diamati dari sikap dan prilaku siswa. Aspek-aspek pengamatan tersbut merupakan sikap siswa yang muncul saat pelaksanaan pembelajaran.Lembar penilaian aspek afektif diisi dengan cara menskor pada tiap kriteria yang diamati.Kemendikbud (2014:92) menjelaskan bahwa setiap aspek dari indikator yang muncul diberi skor berupa angka. Skor tersebut dibuat dengan rentangan 1 sampai 4. Teknik analisis data dalam penelitian ini untuk melihat kompetensi afektif siswa dengan menggunakan uji Mann Wtihney $U$ (uji U)dengan $\alpha=0,05$.

\section{HASIL DAN PEMBAHASAN}

Setelah serangkaian penelitian dilaksanakan, selanjutnya dilakukan analisis terhadap data yang dihasilkan. Analisis data dilakukan untuk mengungkapkan pengaruhmodel pembelajaran kooperatif tipe Think Pair Share (TPS) dan kemampuan awal terhadap kompetensi ranah afektif biologi siswa kelas VIII SMPN 38 Sijunjung.

Hasil pengamatan kompetensi ranah afektif siswa yang dilakukan oleh observer, diperoleh data bahwa kompetensi afektif kelas eksperimen lebih baik secara signifikan daripada kompetensi afektif siswa kelas kontrol. Kompetensi ranah afektif siswa pada kelas eksperimen secara keseluruhan memperoleh predikat baik, 
sedangkan kelas kontrol memperoleh predikat cukup.

Siswa pada kelas eksperimen sebagian besar mau mendengar penjelasan guru dengan sungguh-sungguh, duduk tenang dengan seksama mengikuti jalannya diskusi, bekerja sama dalam diskusi kelompok dengan baik dan antusias menyumbangkan pendapatnya untuk penyelesaian LKS. Siswa aktif dalam mengajukan pertanyaan dengan pasangaan dan saat diskusi dengan kelompok lainnya, dan sesuai dengan permasalahan yang sedang dipelajari.

Siswa juga mampu menanggapi teman yang berpendapat dan tidak saling menjatuhkan teman, serta aktif dalam mengajukan pendapat yang didasari argumen yang tepat. Hal ini sesuai dengan yang diungkapkan Majid (2014:251) bahwa pada proses pembelajaran siswa perlu memiliki sikap positif, dengan adanya sikap positif dalam diri siswa maka akan tumbuh dan berkembang niat belajar, akan lebih mudah diberi motivasi, dan akan mudah menyerap pelajaran yang diajarkan.

Proses pembelajaran dengan model pembelajaran TPS dilapangan terbukti bahwa ranah afektif siswa lebih tinggi dibandingkan dengan kelas kontrol yang menggunakan metode diskusi. Rasa ingin tahu siswa terhadap materimembuat siswa jadi fokus dan aktif dalam proses pembelajaran, tanggapan, maupun menjawab masalah-masalah yang muncul dalam proses pembelajaran. Kerjasama dalam diskusi tinggi, karena siswa bertanggung jawab baik individu maupun kelompok dalammenjawab pertanyaan-pertanyaan yang ada pada LKS. Ada dua faktor yang mempengaruhi hasil belajar yaitu faktor yang datang dari dalam diri siswa dan faktor yang datang dari luar diri siswa seperti lingkungan belajar siswa (Sudjana, 2005:39).

Pada proses pembelajaran siswa menjawab pertanyaan yang diberikan oleh guru dalam bentuk LKS, sehingga saat proses pembelajaran berlangsung siswa bersemangat menjawab pertanyaan dan jawaban terfokus pada materi pembelajaran yang diberikan. Siswa juga percaya diri menyampaikan masalah yang ditemukan. Hal ini juga terlihat bahwa siswa bertanggung jawab dan bersungguh-sungguh dalam menyelesaikan masalah, siswa saling bersosialisasi dalam berdiskusi. Saat diskusi dimana guru membimbing penyelidikan kelompok, guru hanya mengarahkan sedikit saja untuk pemecahan masalah yang ditemukan, karena siswa saling bekerjasama dalam menyampaikan pemahaman yang telah di dapat dalam proses pembelajaran. Pembelajaran kooperatif dapat mendorong siswauntuk bekerjasama secara maksimal sesuai dengan keadaan kelompoknya (Lie, 2002:65).

Pada proses pembelajaran ketika siswa menampilkan hasil diskusinya, siswa lebih percaya diri menyampaikan jawaban dari LKS dan siswa yang lainpun ikut mendengarkan. Hal ini menunjukkan rasa ingin tahu siswa terhadap pertanyaan mengenai materi pembelajaran. Disaat pasangan kelompok kurang mengerti tentang pertanyaan yang ada, maka teman kelompok lain yang menambahkan, mengkoreksi, bahkan bertanya tentang permasalahan yang dibahas oleh kelompok penyaji. Kelebihan model pembelajaran kooperatif adalah dengan menggunakan model TPS dapat membuat siswa mengemukakan ide atau gagagsan, siswa memiliki rasa ingin tahu yang besar, dan membuat siswa percaya diri (Hardiyanti, 2013:5).

Pada kelas kontrol menggunakan metode diskusi siswa masih kurang aktif dalam proses pembelajaran, siswa masih kurang bekerjasama dalam berdiskusi karena konsep pemahaman dalam pembelajaran yang rendah, sehingga siswa kurang percaya diri dalam bertanya, menanggapi, maupun menjawab pertanyaan-pertanyaan 
yang muncul dalam proses diskusi berlangsung. Siswa tampak jenuh dengan metode yang membosankan dan kurangnya persiapan siswa dalam proses pembelajaran karena aktivitas yang minim. Apabila aktivitas minim, maka sikap dan keterampilan tidak dapat teramati pada saat proses pembelajaran berlangsung.

Dengan kata lain, proses pembelajaran pada kedua sampel yaitu kelas eksperimen dan kelas kontrol terdapat perbedaan yang berarti pada ranah afektif. Kelas eksperimen menggunakan model pembelajaran TPS memiliki rata-rata kompetensi ranah afektif lebih tinggi dibandingkan nilai rata-rata kompetensi ranah afektif kelas kontrol dengan menggunakan metode diskusi. Begitu juga jika dilihat dari kemampuan awal siswa.

Siswa yang berkemampuan awal tinggi juga berpengaruh terhadap penilaian afektif siswa, karena siswa berkemampuan awal tinggi lebih aktif dan mendominasi dalam proses pembelajaran. Sedangkan siswa yang berkemampuan awal rendah kurang aktif, siswa berkemampuan awal tinggi juga membantu menjelaskan jawaban dari LKS dan materikepada teman-teman yang lain. Sehingga keberadaan siswa dengan kemampuan awal tinggi dalam kelompok tersebut ikut membantu dalam diskusi.

\section{PENUTUP}

Berdasarkan hasil penelitian dan pembahasan yang telah dilakukan, maka penulis dapat menyimpulkan bahwaterdapat pengaruh model pembelajaran kooperatif Think Pair Share terhadap kompetensi afektif biologi siswa, baik yang berkemampuan awal tinggi maupun rendah.

Berdasarkan kesimpulan penelitian ini, maka dapat dikemukakan beberapa saran berikut.

1. Diharapkan kepada guru untuk dapat menerapkan strategi dan inovasi pembelajaran untuk meningkatkan kompetensi belajar biologi siswa, salah satunya adalah dengan menerapkan model pembelajaran Think Pair Share.

2. Penelitian ini menggunakan dua kategori kemampuan awal, diharapkan penelitian selanjutnya mengkaji tiga kategori kemampuan awal yaitu rendah, sedang, dan tinggi terhadap semua aspek.

3. Penelitian ini masih terbatas pada materi gerak pada tumbuhan, hama dan penyakit pada tumbuhan. Diharapkan ada penelitian lanjutan pada materi lain dengan sampel yang berbeda. 


\section{UCAPAN TERIMA KASIH}

Ucapan terimakasih penulis sampaikan kepada pihak yang telah membantu dalam penelitian ini kepada Bapak/Ibu validator yaituDr. Linda Advinda, M.Kes, Dr. Darmansyah, M.Pd, Liza Utavia, S.Pt, serta kepada Kepala Sekolah SMPN 38 Sijunjung.

\section{REFERENSI}

Arikunto, S. 2010. Dasar-Dasar Evaluasi pendidikan. Bumi Aksara: Jakarta.

Asih, A. N. 2013. Penerapan Model Pembelajaran Think Pair Share Untuk Meningkatkan Aktivitas Memecahkan Masalah Dan Hasil Belajar Dalam Mata Pelajaran PKN Siswa Kelas VIIIa MTS. Al-Khairiyah Tegallinggah Tahun Ajaran 2012/2013. Jurnal. Singaraja: Jurusan Pendidikan Pancasila Dan Kewarganegaraan.

Hardiyanti, A. 2013. Peningkatan Kreativitas Dan Prestasi Belajar Matematika Melalui Strategi Think Pair Share. Jurnal. Surakarta: Pendidikan Matematika FKIP UMS.

Huda, M. 2011. Cooperative Learning: Metode, Teknik, Struktur, dan Model Penerapan. Yogyakarta: Pustaka Pelajar.

Kemendikbud. 2014. Materi Pelatihan Implementasi Kurikulum 2013 Tahun Ajaran 2014/2015 Mata Pelajaran IPA SMP/MTS. Jakarta: Badan Pengembangan Sumber Daya Manusia Pendidikan dan Kebudayaan.

Lie. A. 2002. Cooperative Learning: Mempraktikan Cooperative Learning Di Ruang-Ruang Kelas. Jakarta: Grasindo.

Lufri. 2007. Strategi PembelajaranBiologi, Teori Praktik dan Penelitian. Padang: UNP Press.

Majid, A. 2014. Implementasi kurikulum 2013 Kajian Teoritis dan Praktis. Bandung: Interes Media.

Kartika. D. 2012. The Effect Of Think-Pair-Share Technique On Students' Reading Comprehension Achievement. Journal. Email: kdhona@yahoo.com 
Pratiwi, R. W. 2011. "Pengaruh Penerapan Pembelajaran Kooperatif TPS terhadap kemampuan mateatika siswa kelas VII SMPN 1 Kecamatan Situjuh Limo Nagari”. Tesis tidak diterbitkan. Padang: Program Pasca Sarjana UNP.

Rusman. 2012. Model-model Pembelajaran Mengembangkan Profesionalisme Guru. Bandung: Rajawali Pers.

Sudjana, N. 2005. Metoda Statistika. Bandung: Tarsito.

Usman, M. 2010. Mendesain Model Pembelajaran Inovatif-Progresif. Jakarta: Kencana Prenada Media Group. 